\title{
A LOCAL BRAND AND “FMOT” OR FIRST MOMENT OF TRUTH
}

\author{
Aivars Helde ${ }^{1}$
}

\begin{abstract}
This study examines the nature of an advertisement with the focus on social discourse and First Moment of Truth(FMOT) in the context of this research. This paper aims at analyzing different commercial advertisements (product/nonproduct ads) to investigate the intentions and techniques of consumer product companies in reaching more consumers and selling more products. First Moment of Truth (FMOT) represents the "a-ha" moment when a consumer is confronted with a product and related alternatives, assumed to take place in everyday life. This is considered to be the point when a consumer decides to buy a specific brand or product. Although commonly the First Moment of Truth as a technique, is used as online or in- store selling, this technique has a crucial role in the perception of print advertising too. "Any time a customer comes into contact with a business, however remote, they have an opportunity to form an impression," said Jan Carlzon, president of Scandinavian Airlines, defining the Moment of Truth in business. It has now crossed over into sales and marketing as others have embraced the term to describe different customer and consumer behavior (Shep Hyken). As soon as people in Latvia-are going to trust to the national brand more, it is very important to focus on the visual manifestation of a local brand. The Norman Fairclough's 3-D model, Kress Van Leeuwen's grammar of visual design, and the French semiotician Roland Barthes(1977) suggested theoretical and semiotic tools for analyzing and understanding advertisements are used to analyzing the data. All materials are taken from the Latvian media.
\end{abstract}

JEL Classification Number: B41; DOI: http://dx.doi.org/10.12955/cbup.v5.918

Keywords: advertising, the photographic message, local brand

As the elements of a marketing program come together to create a complete offering, marketers must also consider how the marketing program will be used to create effective branding and positioning. While the concept of a brand may seem relatively simple to understand, branding strategy can be quite complex. From a technical point of view, a brand is a combination of name, symbol, term, or design that identifies a specific product. Brands have two aspects: the brand name and the brand mark (Ferrell \& Hartline, 2014). The brand name is the part of a brand that can be spoken, including words, letters, and numbers.

The brand mark-which includes symbols, figures, or a design is the part of a brand that cannot be spoken (Nike's swoosh). Jenni Romaniuk, a professor from The Ehrenberg- Bass Institute, says that distinctive assets are the branding elements that uniquely identify the brand across the clear majority of category buyers, such as the Nike swoosh or red and yellow M\&Ms. The opportunity and challenge of distinctive assets is that potential assets can come from a wide source of possibilities, from colors, fonts, advertising style, celebrities, characters or logos, just to name of few. While these technical aspects of branding are important, branding strategy involves much more than developing a clever brand name or unique brand mark. Good brands are those that immediately come to mind when a customer has a problem to solve or a need to fulfill. So, branding strategy is "the battle for your mind" (Ries \& Trout, 2001). However, for most people advertising is something to encourage or persuade them to buy a specific product. Advertisements not only serve this purpose, they "also amuse, inform, misinform, worry, though it may be argued that these functions are all in the service of the main function" (Cook 1992). By the other hand there are non-product advertisements as well that, without promoting any products, only advocate a change in behavior. Such non-product ads are used in different campaigns, and they show the effects of not adopting the advocated behavior. "Ads may not always be obliged to refer to a product, but they are still obliged to refer, however obliquely, to a change of behavior." (Cook 1992). Today it is very common to use a third possibility-to combine these techniques and promote a product using different cultural and behavioral stereotypes. The aim of this type of advertisements is not to change habits of behavior but on the contrary-to maintain or strengthen these habits. Cook (1992) remarks that "Advertising is not a remote and specialized discourse, but a prominent discourse type in contemporary society." In order to understand and study the images, one must be aware that they are created with social power and influenced by ideology. The term "ideology" in this case is an understood belief system, which exists in all cultures. Tuen van Dijk, founder of critical discourse, in terms of the concept of "ideology" gives us several of these important aspects. First, the ideology as a kind of "idea system" refers to the processes of cognition. Second, the ideology is social and is often associated with a group of interests, conflicts, and battles. Ideologies

\footnotetext{
${ }^{1}$ RISEBA University, Riga, Latvia, awhelds1@ inbox.lv
} 
can be used to legitimize or, conversely, removing power and domination, often it symbolizes social problems or inconsistencies. Third, the ideology associated with the use of language or discourse, to indicate how it is expressed or reproduced in society. "If we want to know what are ideologies, how they work and how they are created, modified and reproduced, we need to carefully analyze the discursive manifestation" (Van Dijk, 1998). Sturken and Cartwright believe that ideology is an extensive and irreplaceable set of common values and views, one in which individuals survive their difficult relations with the large range of social structures (2001). Pictures are a major tool by which ideology is produced and to which ideology is projected. Visual culture is essential for power and ideological relations. Discourse is described by Gee $(1989,2005)$ as "language" (oral or written) in use with more socio-politically oriented meaning" Fairclough $(1989,1995)$ goes further and defines it as "just a particular form of social practice". In other words, discourse constitutes social practice and is at that some time constituted by it. (Wodak, 1997). Inter-textuality has been described as text (which) is recognized in terms of their dependence on other relevant text. Essentially, it amounts to the relationship between text and the various languages or signifying practices of that culture. Therefore, one reason for the success of an advertisement or commercial may well be the underlying relationship between its presentation and a literary association familiar to the target audience. "Standard and messaging and conventional creative executions and placement are rapidly becoming outmoded. To win a consumer' $s$ attention and trust, marketers must think less about what advertising says to its target and more about what it does for them" (Rayport, 2013). In respect of connotative mechanisms it would be good to use Roland Barthes "Rhetoric of Image and the photographic Message", his essays gets us tools for semiotic understanding of advertisements. In "Rhetoric of image" he separates one ad into three messages: the "linguistic message" that includes all the textual information, the "symbolic message'-the connoted image and the 'literal message' that refers to non-coded meanings that derive from the denoted image, all non-verbal elements in the image that do not have any cultural code. For Barthes, 'the common domain of the signifies of connotation is that of ideology, which cannot be single for a given society and history, no matter what signifiers of connotation it may use (1977) Through a semiotic analysis, we can argue that these ideological representations in advertisements are assigned meanings to products or services.

In this case, Moment marketing or FMOT (pronounced EFF-mot), is a technique that can help marketers realize their idea about design communication. FMOT is the 3-7 seconds after a shopper first encounters a product on a store shelf or outdoor ad. It is these precious few seconds that advertisers have the best chance of converting buyers mind or create new understanding for a product by appealing to their senses, values, and emotions. Communication design focused around these lifechanging messages can alter the whole perception towards the communication design field, from being a decorative aesthetically driven expenditure to becoming a significant investment that makes lives possible, easier and better.

"The public good must be the most important objective of design activity, and it should be sought with the best resources, being understood as an investment with high returns affecting hidden dimensions of the economy." (Frascara, 2002, p.35). Visual culture, of course, does not depend on pictures only, but visualization of different situations and meanings play very important role in our society. Researcher Mirzoeff (1998) believes that visual culture is a kind of crisis information and that everyday life is filled with visualization. He believes that post-modernity in which we live is the ocular centrist. This happens because we are becoming more and more operate and interact with fully constructed visual manifestations. Mirzoeff stresses that the first step towards the visual culture is the understanding that the visual image is not stable, but varies depending on relations with the external reality of modernity in certain moments (1999). Rogoff (1995) believes that visual culture as a transdisciplinary and between methodological approaches to development provides an opportunity to reflect on the culture's most complex problems in another aspect. This approach allows you to look at some of the problems that are updated visual culture, such as the presence and the absence, shortage, invisibility, stereotyping, wishes, reflection, and objectification (Zitmane, 2015).

Talking about advertising the situation for the local brand is more favorable. Local manufacturers know their consumer behavior much better because they themselves are part of this behavioral model implementers. However, in the reality faced there are situations where a vendor claims to be socially responsible, even though actually it is only a marketing trick. 
Ideological meanings are often idealistic, mythical significations assigned through connotative verbal and non-verbal elements of the advertisements. So, the nature of the experience is what needs to be considered -what does the consumer require when making this purchase decision? In his book - "Paid attention" Faris Yakob wrote: 'Consumers need different brands to do different things. The clear majority of purchases do not adhere to a purchase funnel at all- they are made impulsively. Since there is, or there is perceived to be, functional parity among the primary competitors, we need to have only a very slight preference for a brand to aid the decision. Other purchases have different contextual needs that brands help to fulfills. There are always is combinations of rational and emotional needs that brands satisfy. The needs of consumers and the drivers of their behavior are variable. By looking at some of the veiled aspects of attention and cognition, we can begin to understand better people and brands, and how they interact. (Faris, 2015).

\section{Statement of the problem and Purpose}

The nature and importance of brand identity and brand image has been highlighted by many leading scientists on brand management and strategy. This has typically been done in the context of products, services or product and non-product advertising. Many studies of advertising, separate out components of ads, concentrating on one or a few and ignoring the others. There are some theories that are traditionally used, such as Fairclough' s 3D model or Kress and Van Leeuwen's visual grammar or Roland Barthes semiotics and rhetoric of advertising for consumers. Before dealing with ads analysis, it is worthwhile to explain what is meant by successful ads. These are described in their three basic parameters: strategy, creativity, and fabrication. The strategy constitutes a specific target selection, the target audience's choice, the report creation, and media planning- Describing advertising as discourse is both more complex and more difficult than any of these approaches. It must be taken into consideration then that there is a danger of dilution in the analysis which attempts to tackle too much. Professionals advise marketers to approach this medium as a landscape composed of four domains: the public sphere, where we move from one place or activity to another, the social sphere, where we interact with and relate to one another, the tribal sphere, where we affiliate with groups to define or express our identity, and the psychological sphere, where we connect language with specific thoughts and feelings (Rayport \& Jarowski, 2004). The dominant approach in cultural studies for analyzing ads has without doubt been semiotics. Many key arguments about the way ads perpetuate and feed dominant ideologies, about the way they construct audiences as consumers, and about the impact they have on culture more generally, are grounded in semiotic analysis. The problem is that the theoretical basis for those analyses has been chipped away at (e.g., Corner, 1983, Pateman, 1990), and if we are to rescue a strong critical, textually informed approach to ads, we need to supplement semiotics with theories of the social. "Semiotic analysis - in stark contrast to discourse analysis - begins by theoretically separating out of the realm of the symbolic, including language, and other sign systems such as the meaning of images, from the realm of social. The kind of analysis has worked well with ads partly because they appear pure semiosis with few traces of actual social and communicative activity. Ads often have no obvious senders. They are designed for a large audience to make sense of rather than a specific group, providing positions for us to locate ourselves within consumer culture. They are also divorced from their co-text: an ad on a bus has nothing to do with the bus, and thus require consumers to invoke the semiotic system needed to interpret them by themselves." (Matheson, 2005) "Media discourses"

This study will focus on Latvian ads with effect of social discourse as a principle of a brand communication with the customer and FMOT based on customer cultural habits and expectations.

\section{Scope and research Questions}

This study employs quantitative and qualitative analyses, based on a content analysis and Kress and Van Luween' $s$ visual grammars interpretation of advertisements. Taking into consideration that advertisements targeting local consumers are associated with national affiliations, the current study aims to answer the following questions:

(1) Which categories that conceptualized national identity are evident and significantly present in the advertisements of a local brands of Latvia

(2) What cultural meanings are assigned to the national affiliation categories in respect of verbal and non-verbal components in the visual corpus? 
(3) Do FMOT induce a brand mark or a brand name to the national affiliation categories in the visual corpus?

"If human experience is a medium for advertising, how can marketers engage consumers there in a way they will welcome?" (Rayport, 2013). Rather than focusing first on a communication strategy and marketing mix, they should begin by considering how consumers live their lives and under what circumstances they will prove receptive to messages in this domain. For analyzing different advertisements, product ads and non-product ads have been selected. The answers of researched questions are not possible if we do not pull back the "ideological curtain" to see the power and ideology behind images, the chosen ads are predominantly visual. In other words, they communicate through images and pictures.

\section{Methodology and corpus}

The advertisements are from Latvian media and include brand promotion through social discourse. The dimensions of discourse and discourse analysis can be described as follows:

1) Text description; representing, relating, identifying positions for text analysis;

2) Discursive practices (analysis/interpretation: position for processing);

3) Social practices-social analysis/explanation

So, we can call, the first dimension is text analysis or description, the second dimension is processing analysis or interpretation, and the third dimension, social analysis or explanation. All dimensions are interdependent, and therefore it does not matter which kind of analysis one starts with. The series variables common to similar investigations were selected to provide a coding scheme. More specifically, seven categories identifying nationhood in advertisements were defined in the coding frame, as follow:

1) Geographic references/locations: distinctive landscape and landmarks

2) Leisure practices: popular activities

3) Cultural heritage; historical and cultural icon figures

4) Social relationships and social values: family, friendship

5) Objects: distinctive objects

6) Food/ drinks

7) National symbols (Hogan 1999; Edensor 2002)

In addition to the semiotic approach, verbal and non-verbal signs were identified using Barthes' theoretical model of depicting linguistic messages, coded and non-coded iconic messages of advertisements (1977). Denotation and connotation combine to construct ideology and, based on Barthes arguments, denotation refers to the first order of signification and reflects literal meaning. Connotation refers to the second order of signification and reflects cultural, 'constructed' values which are attached to a sign.

\section{Materials}

Four different advertisements -product ads and non-product ads have been selected for analysis. The chosen advertisements communicate through images and pictures. The chosen advertisements communicate through images and pictures.

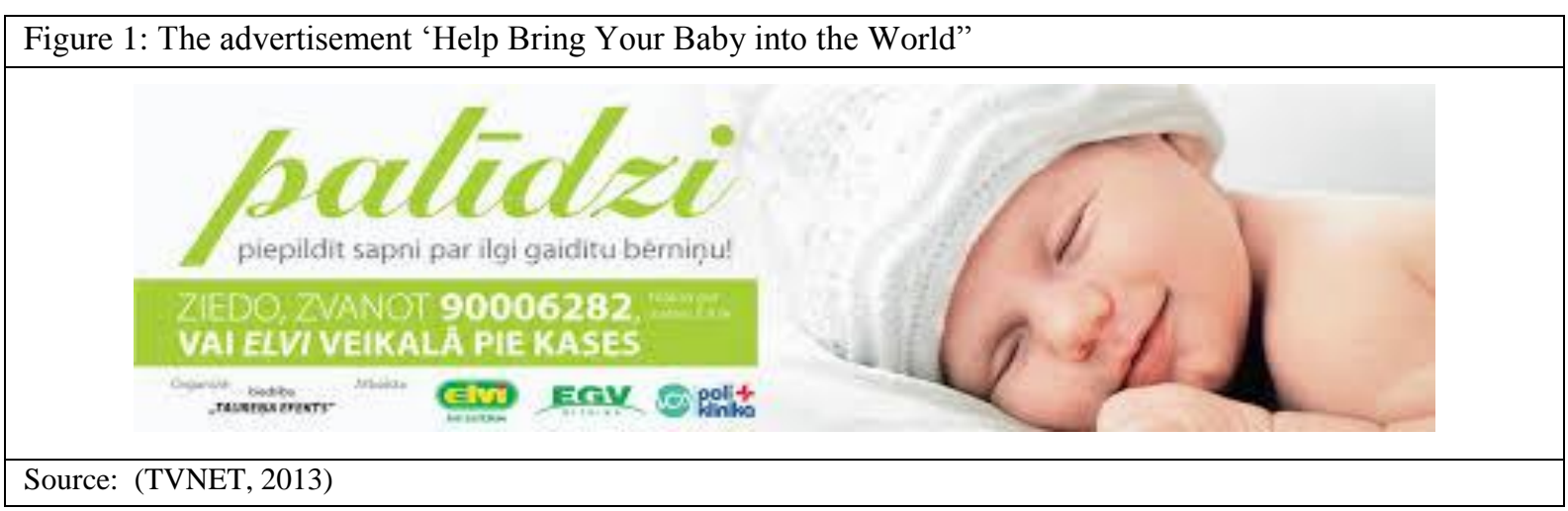



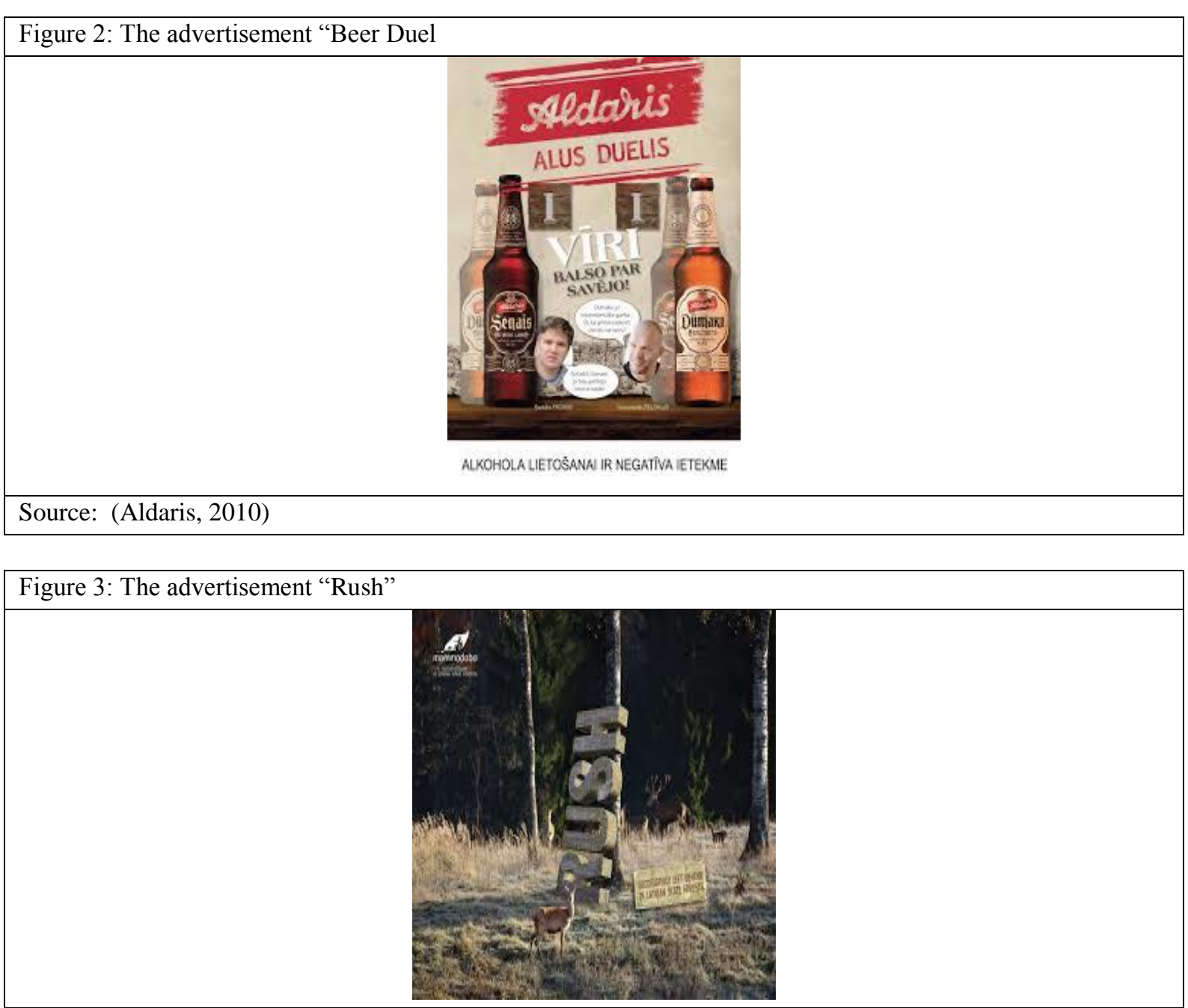

Source: (LVM, 2012)

Figure 4: The advertisement "For a Real Childhood"

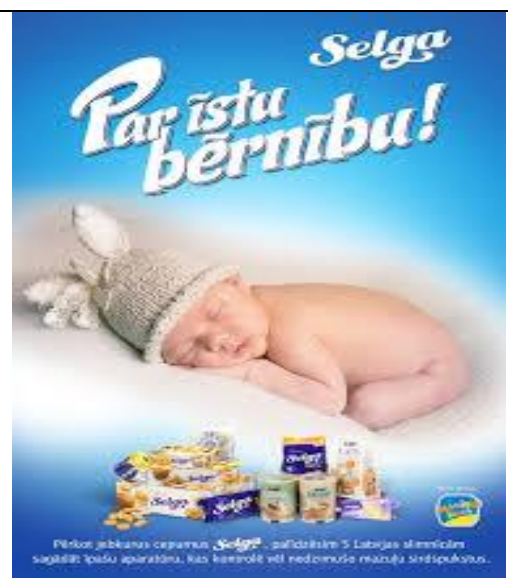

Source: (Selga, 2014)

\section{Results and semiotic analysis of advertisements}

The study was relevant to seven chosen cultural meanings, the dimensions of discourse and discourse analysis.

The "Elvi" (Supermarket Chain) Campaign - "Help Bring Your Baby into the World"This is the picture of a happy smiling baby, (see Figure 1). The company "Elvis" the producer of this ad, (It 
seems that there is the text "Help! To make dreams come true, donate by calling or in the" Elvi" store at point of purchase."

The colors in this advertisement are light; the accent is not on the baby but the first text phrase with 'help' written in green color. The viewer is almost too intimate with the baby who is next to the text. This ad is considered to be for charity. It is trying to solve a problem. Thus the result, the viewer has the power to be involved or not. There is no power above to force her/him. From the point of cultural meanings, this advertisement shows us "Our" proposes the idea of Collectiveness by suggesting an imaginary community, that shares and adopts the concept of mutuality. In the current example "we take care of "our" families.

The "Aldaris" (Beverage Manufacturer) The advertisement "Beer duel."

We see a complex picture. In the first plan, we see two beer bottles, labels indicate that to the right is the "haze" but to the left the "ancient." Deliberately the bottles are presented from such point of view, so after "haze" - "ancient" followed by "ancient" - "haze". Visible in the background of two men in the face, both Latvian recognizable people. In addition, one of them with dark hair, while the other is bald headed. At the advertisement top we see inscription- "Aldaris," below this is text- "Men vote for our own folks" and the texts, which are located in circles, and, as can be understood to say the men in the picture. On the right side is the wrestler Zelonijs, he says-haze because it looks like more interesting taste, as will to eat some fish or cheese, luge rider Prūsis, he says- certainly "ancient" bee, it tastes much better. The colors used in this ad are brown and beige. These two men faces attract the viewer's attention and encourage her/him to read the ad. This ad gives the viewer a sense of rivalry. The eyelevel angle shows that the power balance is on the side of the viewer and he is the real judge. Thus, the viewer feel inclined to obey the advertisement, preferring his idol. From the point of cultural meaning, we can observe that historic authenticity is another ideal that use local brands. Food/drink were found to have a significant effect on the representation of nationhood. More specifically, when beer is used, there was some evenly distributed preferences for traditional products.

The "Mama daba" (On the one hand, the task of "Latvijas valsts mezi" is plain and simple - to manage the forests belonging to the state of Latvia. On the other hand, we would like to contribute by bringing people closer to nature. Hence, "Mammadaba" - Mother Nature - a structural unit of "Latvijas valsts meži", which aims at acquainting local resident and foreign guests with the richness of nature here and helping everyone become one with its primeval beauty). The advertisement "Rush"

This is a non-product ad, about how to regain strength and emotion of our hectic everyday life (See figure 3). As a result, its discourse is social responsibility in highlighting a social problem. The colors in this advertisement are autumn, and soothing. In the background, it is dominated by saturated green tones. The picture is rich with the forest animals. At the top of the advertisement we see the logo by "Mammadaba" and slogan "Active leisure in LATVIAN State Forests" but at the right corner, we see an inscription which complements the center of the display where we see the word "Rush"successfully left Behind in Latvian State Forests. This ad aims to draw attention to a problem. As a result, the viewer feels inclined to obey the advertisement. From the point of cultural meaning we can observe wild nature, signifying an essence of ecology, that we, collectively, in Latvia love our clean and wild forests, the environment for our guests.

The sweets Manufacturer "Laima"

Here we have picture of a baby on a pale-pink cloud (see Figure 4). The colors used in this ad are blue, white, and pale pink. The color blue gives the viewer peace, the color white offers contrast, and color pale pink in middle of the picture of the baby attracts the viewer's attention and invites her/him to buy the biscuits that lie below the picture of the baby. Above this picture the following is written in white:" For a Real Childhood, Selga". Below the biscuits is explanatory text: "Buying any biscuits "Selga" help 5 Latvian hospitals present special apparatus that controls the unborn baby's heartbeats". The company "Laima" is producer of this product (biscuit) ad, which aims to present the company as a socially responsible one that cares about children. The discourse of this "Laima" product could be considered as charity. Therefore, the viewer has the power to choose the biscuit or not. There is no force. From the point of cultural meaning-the pronoun "our", what mean a responsibility and collectiveness. Specifically, in the current example, 'we are taking care of 'our' baby, which provides the moral center of this narrative. 


\section{From the point of the first moment of truth}

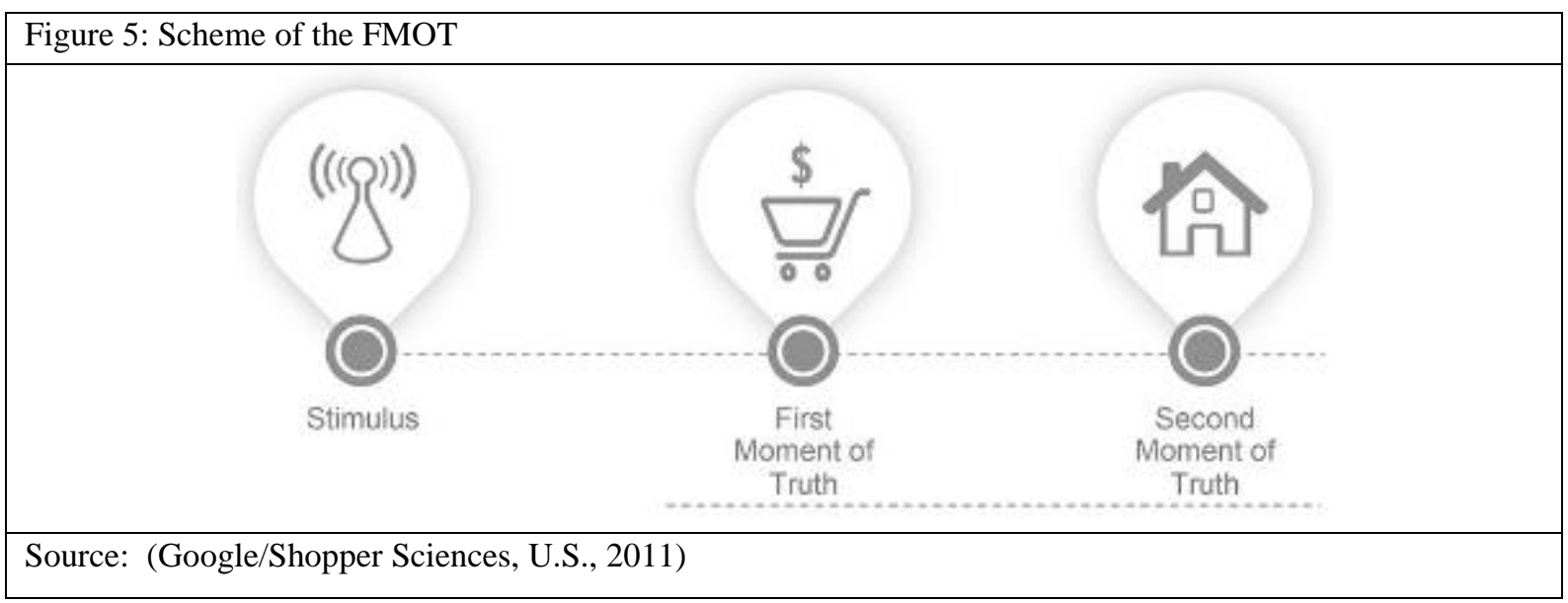

Text and picture make coherent sense by the ways they instantiate structures of meaning.

"Though these may seem like fine distinctions, they are crucial. They suggest that we may be able to talk about what happened in the images and texts in a specifically textual way, without having recourse to hypotheses about what their sender may have intended them to mean, or without having to guess about their effects on a single given receiver. In short, the separation of addresser from sender and addresser from receiver is what lets us do semiotics rather than psychology (Thwaites, Lloyd, Warwick, 2002).

In addition, from the point of FMOT - it is important to mention that these findings show us how FMOT may work for print ads. For example, in the first and fourth situation "Help Bring Your Baby into the World", "For a real childhood" - Our attention is attracted by the call to help (in the first case it is found in the second to understand the unconscious level that we have to protect, care for children), along with the child's picture, acting as a stimulus, followed by empathy and understanding of the nature of the (internal reaction force of human empathy, moral maturity, option) and the social experience. Incentive and experience are equally important moments in a determined man's further action. The second example, the ad of the "Beer duel"- advertising legend and the image stops us even confuses us, while incentive arises in addressing the question of a visual puzzle on already incurred emotion-smile.The advertisement "Rush" works in otherwise, there is an incentive for even more specifics, it is connected with the desire to examine, explore.

\section{Conclusions}

"All living human beings communicate through sounds, speech, movements, gestures, and language. Communication involves many human activities, speaking, listening, reading, writing, viewing, and creating images. How people communicate is based on cultural conventions that are adhered to in interacting with other people, in producing and sending messages and interpreting messages" (de Mooji, 2014).

A content analysis of local brand advertisements has revealed that, in respect of nationhood. The purpose of this study was to analyze advertisements, product ads, and non-product ads, in order to see when the producers use their power to imply something to the viewer, while at the same time paying attention to the process called the First moment of truth. The analyses showed us that in modern days it is very common to use the focus on social discourse for commercial ads. This technique allows producers to cultivate better relations between the viewers (consumers) and the company. In this case, we should use power in discourse as a form of social practices which are themselves shaped and constituted by power relations. In analyzing these advertisements and defining the position of the viewers, the followings conclusions were made. The producers try to show that the viewer has the power to choose or not to choose something. All meanings were explored in respect of the Latvian sociopolitical context and portrayed through visual communication. These cultural meanings are very much related to the social characteristics of the people and their daily practices of every day. As Rogoff wrote in "Visual methodologies": 
Visual imagery is never innocent; it is always constructed through various practices, technologies, and knowledge.

The meaning of an image or set of images are made at the three sites: the site of production, the image itself, and its audiencing

There are three modalities to reach of sites: technological, compositional, and social

Theoretical debates about how to interpret images can be understood as debates over which of this sites and modalities is most important for understanding an image.

A local brand has a great advantage because they are able to reach their potential audience, based on national identity. This is very important especially in times when there is increasing competition in the market, and in the local market too. The current research would provide additional and useful results about image identity from the viewers' perspective in local brand advertisements.

\section{References}

Aldaris. (27. July 2010). Aldaris Alus duelis: Prūsis un Zeļonijs [Aldaris Beer Duel: Prussia and Zealoni]. Načteno z sportacentrs.com: http://sportacentrs.com/aldara_duelis/27072010-aldaris_alus_duelis_prusis_un_zelonijs

Anderson, B. (2006) "Imagined Communities". New Yourk: Verso.

Barthes, R. (1977) "Image-Music-text.” London Fantana Press

Beasley, R., \& Daneisi, M. (2002) "Persuasive Signs:The semioticsOf Advertising.”Berlin,NY” Mouton de Gruytere Berger, J., Way of Seeing (1972)

Borns, L. \& Ruso, N. (2001) Psychology, Riga, Latvia, Raka Ltd.

Cook, G. (1992) The Discourse of Advertising, Routledge

Corner, J. (1983) Textuality, Communicatio and Power.Semiotics for Beginners by Daniel Chandler-http://visualmemory.co.uk/daniel/Documents/S4B/

De Mooji, M. (2014). Global Marketing and Advertising: Understanding Cultural Paradoxes, 4th ed. Sage Publications Fairclough, A. (1995), International Journal of Lingustics 4(4)

Fairclugh, N. (1989) Language and power. Harlow: Longman,Critical discourse analysis: The critical study of language. London Longman

Faris, Y. (2015) Paid Attention:Innovative Advertising forDigital Worl,Cambridge Marketing Handbooks

Ferrell, O.C. \& Hartline, M.D. (2014), Marketing Strategy Text and Cases, 6th ed. South-Western Cengage Learning, Library of Congress Control

Frascara, J. (2002) Design and the Social Sciences: Marketing Communications, CRC Press

Gee, J.P. (2005) An Introduction to Discourse Analysis -Theory and Cases.6th ed. South-Western Cengage Learning, Library of Congress Control

Google/Shopper Sciences, U.S. (April 2011). The Zero Moment of Truth for Consumer Electronics Study. Načteno z Thinkwithgoogle: https://www.thinkwithgoogle.com/consumer-insights/zmot-consumer-electronics/

Hyken, S. (https://www.forbes.com/sites/shephyken/2016/04/09/new-moment-of-truth-in-business/\#643daa7538d9)

Kelly, A., Lawlor, K. and O’Donohoe, S. (2009) Chapter 8- Encoding Advertisements: The Creative Perspective. "In the Advertising and Consumer Culture Reader, edited by J. Turow and M. P. McAllister. NY: Routledge

Kress, G. \& van Leeuwen, T. (1990), Reading Images. Victoria: Deakin University Press, 1996.Reading Images: The Grammar of Visual Design. New York: Routledge

Kress, G. \& van Leeuwen, T. (1996), Reading Images: The Grammar of Visual Design. London: Routledge. pp. 15-16.

LVM. (2012). Mammadaba iekḷūst pasaules mēroga reklāmas žurnālā [Mammadaba enters the world-wide magazine]. Načteno z Lvm.lv: http://www.lvm.lv/jaunumi/arhivs/2012/1471-mammadaba-ieklust-pasaules-meroga-reklamas-zurnala

Matheson, D. (2005) Media Discourse, Open University press

Mirzoeff, N. (2012) The Visual Culture Reader Routledge; 3rd edition.

Pateman, C. (1980) The Problem of Political Obligation, Political Theory, Vol. 8, No. 3., Sage Publications Inc.

Rayport, J.F. \& Jaworski, B.J. (2014), Best Face Forward: Why Companies Must Improve Their Service Interface with Customers. Harvard Business School Press.

Rayport, J.F. (2013) Advertising's New Medium: Human Experience - Harvard Business Review, March edition

Ries, A. \& Trout, J. (2001) Positioning: The Batles for Your Mind, Mc-Graw-Hill.

Rogoff, I. (1995) Studying Visual culture

Selga. (8. April 2014). Selga kopā ar Māminuu Klubu vienojas akcijā "Par īstu bērnību!". Piedalies! [Selga agrees with Mother Club in the action "For a real childhood!". Take part!]. Načteno z maminuklubs.lv: http://www.maminuklubs.lv/mk/zimolsselga-paplasina-socialas-atbildibas-darbu-244792/

Sturken, M., Cartwright, L. (2009) The Oxford University Press; 2nd edition 
Taylor, J., Francis, A., Hall, S. (1973) Encoding and decoding in the Television Discourse Birmingham. England: Centrefor Cultural Studies, University of Birmingham

Thwaites, T., Lloyd, D., Warwick, M. (2002) Introducting Cultural and Media Studies: A Semiotic Approach, Palgrave TVNET. (10. May 2013). http://www.tvnet.lv/egoiste/egoiste_iesaka/463746-

sakta_sociala_kampana_lai_palidzetu_piecam_neaugligam_gimenem. Načteno z http://www.tvnet.lv/egoiste/egoiste_iesaka/463746-sakta_sociala_kampana_lai_palidzetu_piecam_neaugligam_gimenem Van Dijk, T.A., (1998) Ideology. A Multidisciplinary Approach. London: Sage Publications.

Wodak, R. (1997) ender and Discourse, Sage Publications. The Discursive Construction of National Identity. Edinburgh Zantides, E. (2016) Visual studies Vol. 31. No 3, 248-259, http://dx.doi.org/10.10801472586X.2016.1209987

Zitmane, M. (2015) "Patērētāja(at) veidojums Latvijas žurnālu reklāmās periodikas un pēcpadomju periodā: dzimtes identitātes diskurss*198502004)promocijas darbs 